\title{
Case 1-2011: A 60 years Old Male with Coma and Fever with Recent Travel to South Sudan
}

\author{
Tarik Zaher, Nahla Elgammal , Dina Mohamed
}

tareqzaher@zu.edu.eg

\section{Presentation of the case:}

A 60 years -old business man admitted to the intensive care unit of the Endemic and Tropical Medicine Department, Faculty of Medicine , Zagazig University, Egypt because of deep coma, fever and tachypnea.

The patient had history of recent travel to Juba, south of Sudan 2 weeks befor admission. 5 days after return from Sudan, he noticed fatigue and mild fever.He was given non-specific treatment. 5 days later jaundice appeared on his skin, he was admitted to private hospital in Zagazig .The investigation showed total bilirubin :10 mg/dl, direct $7 \mathrm{mg} / \mathrm{dl}$, ALT:150 , AST :120,Hg :10 gm/dl ,platelets : $110000 / \mathrm{dl}$.The patient was managed as having acute liver disease. Later on malaria parasite test (MP test) was done and revealed $P$. falciparum in thick and thin blood films. The patient was referred to Zagazig Fever Hospital with deterioration of conscious level, quinine was given intravenously without improvement. In the next day, the patient was referred to Tropical Medicine Intensive Care Unit. The patient was deeply comatose ,deeply jaundiced and pale, splenomegaly was found, bubbling chest crepitations were auscultated.The urine was black and the skin showed echymosis .The investigations showed total bilirubin :32 mg /dl, direct bilirubin $22 \mathrm{mg} / \mathrm{dl}, \mathrm{Hg}: 6 \mathrm{gm} / \mathrm{dl}$ ,platelets : 15000/dl, creatinin: $6 \mathrm{mg} / \mathrm{dl}$, INR :7 ,PH: 7.31 , bicarbonate :12 $\mathrm{mmol} / \mathrm{l}$ and glucose : $350 \mathrm{mg} / \mathrm{dl}$. Hemoglobin was found in urine. Quinine was given by intravenous infusion in the dose of $20 \mathrm{mg} / \mathrm{kg}$ loading dose then $10 \mathrm{mg} / \mathrm{kg}$ every 8 hours. Doxycyclin $100 \mathrm{mg} / 12$ hours was given through the Ryle. Intravenous frusemide was given as well as oxygen inhalation as a measure against pulmonary edema, also chest consultation for the possibility of mechanical ventilation was requested.Transfusion of platelets, fresh frozen plasma ,and backed red blood cells were given. Intravenous fluids as glucose $10 \%$ with 15 unit regular insulin and Ringer lactate solution were given according to the CVP. Regular insulin according to blood glucose level was given every 6 hours subcutaneously. The patient showed no response after one day of extensive care and death was the the end due to multiple organ failure .

\section{Differential diagnosis:}

Febrile coma:Febrile coma occurs in cerebral malaria, meningitis , encephalitis, heat stroke, cerebral and pontine hemorrhage, hepatic coma, diabetic coma with infection and atropine poisoning[1].

Fever with jaundice: Fever accompanied by jaundice is caused by viral hepatitis, falciparum malaria , paratyphoid B, infectious mononucleosis, Weil 's disease, hemolytic crises, septic cholangitis, acute leukaemia, yellow fever and other viral hemorrhagic fevers as rift valley fever [1].

\section{Discussion:}

The above case is a case of severe malaria according to WHO definition of severe malaria[2] due to presence of coma, renal failure, pulmonary edema, high INR ,hemoglobinuria and acidemia . 


\section{Table 1 -- 1990 WHO Definition of severe malaria[2]}

1. Cerebral malaria - unrousable coma not attributable to any other cause in a patient with falciparum malaria. The coma should persist for at least $30 \mathrm{~min}$ ( $1 \mathrm{~h}$ in the 2000 definition) after a generalized convulsion to make the distinction from transient postictal coma. Coma should be assessed using the Blantyre coma scale in children or the Glasgow coma scale in adults.

2. Severe anaemia - normocytic anaemia with haematocrit $<15 \%$ or haemoglobin $<5 \mathrm{~g} / \mathrm{dL}$ in the presence of parasitaemia more than $10000 / \mu \mathrm{L}$. Note that finger prick samples may underestimate the haemoglobin concentration by up to $1 \mathrm{~g}$ if the finger is squeezed. If anaemia is hypochromic and/or microcytic, iron deficiency and thalassaemia/haemoglobinopathy must be excluded. (These criteria are rather generous; and would include many children in high transmission areas. A parasitaemia of $>100000 / \mu \mathrm{L}$ might be a more appropriate threshold.)

3. Renal failure - defined as a urine output of $<400 \mathrm{~mL}$ in $24 \mathrm{~h}$ in adults, or $12 \mathrm{~mL} / \mathrm{kg}$ in $24 \mathrm{~h}$ in children, failing to improve after rehydration, and a serum creatinine of more than $265 \mu \mathrm{mol} / \mathrm{L}(>3.0 \mathrm{mg} / \mathrm{dL}$ ). (In practice for initial assessment, the serum creatinine alone is used.)

4. Pulmonary oedema or adult respiratory distress syndrome.

5. Hypoglycaemia - defined as a whole blood glucose concentration of less than $2.2 \mathrm{mmol} / \mathrm{L}(40 \mathrm{mg} / \mathrm{dL})$.

6. Circulatory collapse or shock - hypotension (systolic blood pressure $<50 \mathrm{mmHg}$ in children aged $1-5$ years or $<70 \mathrm{mmHg}$ in adults), with cold clammy skin or core-skin temperature difference $>10^{\circ} \mathrm{C}$. (The more recent review declined to give precise definitions, but noted the lack of sensitivity or specificity of core-peripheral measurements.) Capillary refill time is not mentioned but recent studies indicate this simple test provides a good assessment of severity.

7. Spontaneous bleeding from gums, nose, gastrointestinal tract, etc. and/or substantial laboratory evidence of DIC. (This is relatively unusual.)

8. Repeated generalized convulsions - more than two observed within $24 \mathrm{~h}$ despite cooling. (In young children, these may be febrile convulsions, and the other clinical and parasitological features need to be taken into account.) Clinical evidence of seizure activity may be subtle (e.g. tonic clonic eye movements, profuse salivation, delayed coma recovery).

9. Acidaemia - defined as an arterial or capillary $\mathrm{pH}<7.35$ (note temperature corrections are needed as most patients are hotter than $37^{\circ} \mathrm{C}$; add $0.0147 \mathrm{pH}$ unit per degree Celsius $\left({ }^{\circ} \mathrm{C}\right)$ over $37^{\circ} \mathrm{C}$ ), or acidosis defined as a plasma bicarbonate concentration $<15 \mathrm{mmol} / \mathrm{L}$ or a base excess $>10$. (Operationally, the clinical presentation of 'respiratory distress' or 'acidotic breathing' is focused upon in the 2000 recommendations. Abnormal breathing patterns are a sign of severity indicating severe acidosis, pulmonary oedema or pneumonia.)

10. Macroscopic hemoglobinuria - if definitely associated with acute malaria infection and not merely the result of oxidant antimalarial drugs in patients with erythrocyte enzyme defects such as G6PD deficiency. (This is difficult to ascertain in practice: if the G6PD status is checked following massive haemolysis, the value in the remaining red cells may be normal even in mild G6PD deficiency. This part of the definition is not very useful.)

11. Postmortem confirmation of diagnosis. In fatal cases a diagnosis of severe falciparum malaria can be confirmed by histological examination of a postmortem needle necroscopy of the brain. The characteristic features, found especially in cerebral grey matter, are venules/capillaries packed with erythrocytes containing mature trophozoites and schizonts of $P$. falciparum. (These features may not be present in patients who die several days after the start of treatment, although there is usually some residual pigment in the cerebral vessels.)

The 2000 recommendations also include the following:

12. Impairment of consciousness less marked than unrousable coma. (Any impairment of consciousness must be treated seriously). (Assessment using the Glasgow Coma Scale is straightforward, but the Blantyre Scale needs careful local standardization particularly in younger children.)

13. Prostration: Inability to sit unassisted in a child who is normally able to do so. In a child not old enough to sit, this is defined as an inability to feed. This definition is based on examination not history.

14. Hyperparasitaemia - the relation of parasitaemia to severity of illness is different in different populations and age groups, but in general very high parasite densities are associated with increased risk of severe disease, e.g. $>4 \%$ parasitaemia is dangerous in non-immunes, but may be well tolerated in semi-immune children. In non-immune children studied in Thailand a parasitaemia $\geq 4 \%$ carried a 3\% mortality (30 times higher than in all uncomplicated malaria) but in areas of high transmission values much higher may be tolerated well. Many use a threshold definition of $10 \%$ parasitaemia in higher transmission settings.

The followings were not considered criteria of severe malaria:

Jaundice - detected clinically or defined by a serum bilirubin concentration $>50 \mu \mathrm{mol} / \mathrm{L}(3.0 \mathrm{mg} / \mathrm{dL})$. This is only a marker of severe malaria when combined with evidence of other vital organ dysfunction such as coma or renal failure.

Hyperpyrexia - a rectal temperature above $40^{\circ} \mathrm{C}$ in adults and children is no longer considered a sign of severity.

The above case was treated by quinine infusion with doxycyclin by the Ryle as well as by supportive measures for severe malaria.

Treatment of Severe $\boldsymbol{P}$. falciparum Malaria[3]: Regimen 1:

$1^{\text {st }}$ drug

Artesunate $2.4 \mathrm{mg} / \mathrm{kg}$ iv or im on admission; then at $12 \mathrm{~h}$ and $24 \mathrm{~h}$, then once a day for at least

Specific antimalarial treatment:

Zaher et al., Afro-Egyp J Inf End Dis 2011; 1 (2):68-71

www.mis.zu.edu.eg/ajied/home.aspx 
24 hours, followed by full course of ACT(artimisinin combined therapy), and

$2^{\text {nd }}$ drug

Doxycycline $100 \mathrm{mgs}$ BID $(2.2 \mathrm{mg} / \mathrm{kg}$ BID for $<45 \mathrm{kgs}$ ) for 7 days OR Clindamycin 20mg base $/ \mathrm{kg} /$ day divided in three doses for 7 days in pregnancy OR Malaron 4 tab daily for 3 days OR Mefloquine 4 tab in $1^{\text {st }}$ day, 2 tab in $2^{\text {nd }}$ day.

\section{Regimen2:}

$1^{\text {st }}$ drug

Artemether $3.2 \mathrm{mg} / \mathrm{kg}$ i.m. given on admission then $1.6 \mathrm{mg} / \mathrm{kg}$ per day for at least 24 hours, followed by full course of ACT , and

$2^{\text {nd }}$ drug

As above.

\section{Regimen3:}

$1^{\text {st }}$ drug

Quinine $20 \mathrm{mg}$ salt $/ \mathrm{kg}$ on admission (iv infusion or divided im injection), then $10 \mathrm{mg} / \mathrm{kg}$ every 8 $\mathrm{h}$; infusion rate should not exceed $5 \mathrm{mg}$ salt $/ \mathrm{kg}$ per hour; course for 3 days for malaria acquired in Africa and South America, 7 days for malaria acquired in south east (SE) Asia , and $2^{\text {nd }}$ drug

Doxycyclin and clindamycine as above.Do not use mefloquine in combination with quinine.

\section{Regimen 4:}

$1^{\text {st }}$ drug

Quinidine gluconate $10 \mathrm{mg}$ salt $/ \mathrm{kg}$ (equivalent to $6.2 \mathrm{mg}$ base $/ \mathrm{kg}$ ) iv infused over 12 hours, followed immediately by $0.02 \mathrm{mg} / \mathrm{kg} / \mathrm{min}$ salt (equivalent to $0.0125 \mathrm{mg} / \mathrm{kg} / \mathrm{min}$ base) continuous iv infusion; course for 3 days for malaria acquired in Africa and South America, 7 days for malaria acquired in SE Asia, and

$2^{\text {nd }}$ drug

Doxycycline or clindamycin, do not use mefloquine.

\section{ALWAYS AVOID THE FOLLOWING COMBINATIONS:QUININE, MEFLOQUINE, PRIMAQUINE,CHLOROQUINE WITH EACH OTHER.}

Adjunctant Treatment in Severe P.falciparum:

Table -2 Adjunctant treatment [3]:

\begin{tabular}{|c|c|}
\hline Manifestation/complication & Immediate management (in addition to antimalarial treatment) \\
\hline Hyperpyrexia & Administer tepid sponging, fanning, cooling blanket and antipyretic drugs \\
\hline Coma (cerebral malaria) & $\begin{array}{l}\text { Maintain airway, place patient on his or her side, exclude other treatable } \\
\text { causes of coma (e.g. hypoglycaemia, bacterial meningitis); avoid harmful } \\
\text { ancillary treatment such as corticosteroids, heparin and adrenaline; intubate if } \\
\text { necessary }\end{array}$ \\
\hline Convulsions & $\begin{array}{l}\text { Maintain airways; treat promptly with intravenous or rectal diazepam or } \\
\text { intramuscular paraldehyde }\end{array}$ \\
\hline 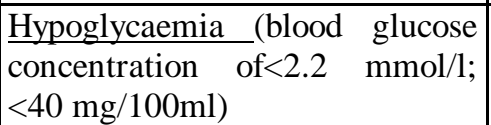 & $\begin{array}{l}\text { Check blood glucose, correct hypoglycaemia and maintain with glucose- } \\
\text { containing infusion }\end{array}$ \\
\hline $\begin{array}{l}\text { Severe anaemia }(\text { haemoglobin }<5 \\
\mathrm{g} / 100 \mathrm{ml} \text { or packed cell volume } \\
<15 \%)\end{array}$ & Transfuse with screened fresh whole blood \\
\hline Acute pulmonary oedema & $\begin{array}{l}\text { Over-enthusiastic rehydration should be avoided so as to prevent pulmonary } \\
\text { oedema. Prop patient up at an angle of } 45^{\circ} \text {, give oxygen, give a diuretic, stop } \\
\text { intravenous fluids, intubate and add positive end-expiratory } \\
\text { pressure/continuous positive airway pressure in life-threatening hypoxaemia }\end{array}$ \\
\hline Acute renal failure & $\begin{array}{l}\text { Exclude pre-renal causes, check fluid balance and urinary sodium; if in } \\
\text { established renal failure add haemofiltration or haemodialysis, or if } \\
\text { unavailable, peritoneal dialysis. The benefits of diuretics/dopamine in acute } \\
\text { renal failure are not proven }\end{array}$ \\
\hline \begin{tabular}{ll|} 
Spontaneous bleeding and \\
coagulopathy
\end{tabular} & Fresh frozen plasma, platelets transfusions, vit K. \\
\hline Metabolic acidosis & $\begin{array}{l}\text { Exclude or treat hypoglycaemia, hypovolaemia and septicaemia. If severe add } \\
\text { haemofiltration or haemodialysis }\end{array}$ \\
\hline$\underline{\text { Shock }}$ & $\begin{array}{l}\text { Suspect septicaemia, take blood for cultures; give parenteral antimicrobials, } \\
\text { correct haemodynamic disturbances }\end{array}$ \\
\hline
\end{tabular}


The above case is an imported malaria because malaria is eradicated from Egypt except small focus in Elfayoum Governorate .In 2007, Zaher et al ,reported a case of imported malaria died by cerebral malaria due to delayed diagnosis before admission to Almaza Military Fever Hospital , Cairo.[4].Also Birnbaumer concluded that death of imported malaria cases was due to miss or delay diagnosis[5].

\section{Conclusion:}

Malaria in travelers typically manifests days or weeks after patients left the endemic area. Malaria symptoms are non specific and rapid diagnosis and treatment are needed .Specific chemoprophylaxis for travelers to chloroquine resistant areas should be given.

\section{References:}

1. Saif El Din S and Abdel Wahab MF.A Guide Book of Tropical and Infectious Diseases. Tropical Medicine Department, Ain Shams University, Cairo 1995;244-246.

2. World Health Organization : Severe falciparum malaria. Trans $R$ Soc Trop Med Hyg 2000; 94(Suppl 1):1-90.

3. Malaria site.www.malariasite.com.

4. Zaher T, Ahmadi M, Ibrahim A,ElBahnasawy M,Gouda H,Shahat S. Malaria in Egypt and Yemen: a clinical pilot study.J Egypt Soc Parasitol 2007;37(3):969-976.

5. Birnbaumer D. Malaria diagnosis missed in nearly half of patients at risk ; Imported malaria prospective analysis of problems in diagnosis and management . Clin Infect Dis $1998 ; 27 ; 142-149$ 